AperTO - Archivio Istituzionale Open Access dell'Università di Torino

\title{
A comparative view of local tax and expenditure limitations and their consequences
}

\section{This is the author's manuscript}

Original Citation:

\section{Availability:}

This version is available http://hdl.handle.net/2318/1594987

since 2016-09-15T14:16:01Z

Publisher:

Edward Elgar

Published version:

DOI: $10.4337 / 9780857932587.00014$

Terms of use:

Open Access

Anyone can freely access the full text of works made available as "Open Access". Works made available under a Creative Commons license can be used according to the terms and conditions of said license. Use of all other works requires consent of the right holder (author or publisher) if not exempted from copyright protection by the applicable law. 


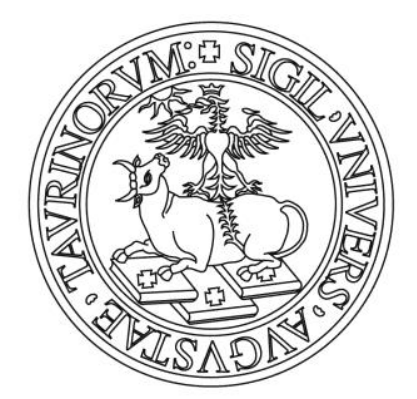

\section{UNIVERSITÀ DEGLI STUDI DI TORINO}

This is an author version of the contribution published in:

Questa è la versione dell'autore dell'opera pubblicata in:

COMPARATIVE LAW AND ECONOMICS

T. Eisenberg, G. Ramello (Eds.)

Edward Elgar, Cheltenham, UK, 2016

pp. $161-181$

The definitive version is available at:

La versione definitiva è disponibile alla URL: www.elgaronline.com 


\section{A comparative view of local tax limits and their consequences}

\section{Federico Revelli}

\section{Introduction}

The size and growth of the local public sector in democratic, multi-tiered structures of government are the outcomes of the decentralized political process, subject to the fiscal rules set by upper - typically, national and state in unitary and federal countries respectively - tiers of government. Quite frequently, besides establishing local governments' domain of competencies, own revenue sources or even the conditions for the very existence of municipal/county tiers (a manifestation of the so-called Dillon's rule in the US local government system, and the de jure or de facto status of local governments in most European countries) those rules contain a number of limitations and obligations that considerably restrict the actual fiscal autonomy of local governments.

Importantly, and partly as a result of the financial crisis of the late 2000s as discussed below, those restrictive fiscal institutions have been playing an increasing role across the developed world in the most recent years. This chapter focuses in particular on the genesis and consequences of tax and expenditure limitations (TELs) on local governments (multipurpose authorities as municipalities, counties or provinces, as well as one-purpose districts), offering a comparison of this sort of intergovernmental fiscal arrangements in the 
amply studied and debated US case, and across some relevant experiences in the countries of Europe that are virtually ignored in academic research. While I focus on specifically local TELs, a related literature deals explicitly with the analysis of the effectiveness and consequences of state TELs on the expenditures and revenues of US states (Mullins and Wallin, 2004; Kousser et al., 2008; Bae et al., 2012).

Within the US federal system, the genesis and consequences of local TELs have attracted and continue to attract considerable attention within the public economics literature, as discussed below. Much less studied are the features and consequences of fiscal limitations on local governments in Europe. Given that several reviews of the US literature have appeared in the past few years, this chapter focuses on the most recent and innovative theoretical and empirical contributions in this area, as well as on the few investigations of the European experiences. In fact, far from being a US-specific fiscal institution, local tax rate limitations are observed almost everywhere across the developed world. In Europe, local tax limitations are in place in virtually all countries, most frequently including the main sources of own revenue of local governments - property, business, income, and consumption taxes - as well as restrictions on the level of surcharges that local governments are allowed to set on upper levels of government's tax levies (usually personal or business income). As documented by Joumard and Kongsrud (2003) and Sutherland et al. (2005), TELs are frequently so tight and pervasive across the developed world and Europe in particular as to jeopardize the very principle of local government fiscal autonomy. A frequently encountered case is a cap on a local tax rate, though several forms of fiscal limitations exist including lower tax rate bounds, admissible annual public spending increases, or local public deficit/debt targets. 
The rest of the chapter is organized as follows. Section 2 first categorizes the observed restrictive fiscal institutions into three main forms (bottom-up, top-down, and self-imposed) according to the nature of the process (participatory, hierarchical or self-disciplining) by which they were originated. Section 3 reviews the theoretical explanations for the existence of TELs in well-developed democratic systems, focusing on the most recent original contributions. Section 4 discusses the recent evidence on the impact of TELs on various aspects of decentralized fiscal policy-making. Finally, section 5 outlines potential avenues for further applied research, and offers some concluding considerations on the foreseeable role of restrictive fiscal institutions in multi-tiered structures of government in an era of fiscal consolidation.

\section{A categorization of local TELs}

\subsection{Bottom-up TELS}

Tax and expenditure limitations on local policy-making authorities are frequently encountered in multi-tiered structures of government. The observed restrictive fiscal institutions can be categorized into three main forms (bottom-up, top-down and selfimposed) according to the nature of the process (participatory, hierarchical, or selfdisciplining) by which they were originated. In particular, an explicit, quantitative restriction on a local government's ability to raise taxes and/or spend on public services be it expressed in terms of statutory tax rate bounds, tax base assessment rules (e.g., admissible property value yearly assessment increase for taxable purposes), per capita levy or aggregate expenditure level and growth limits - is defined here as bottom-up if it shares 
the following two features. First, the fiscal limitation measure can be interpreted as the direct or indirect result of some form of popular movement or initiative to limit the overall size of local government and/or alter its tax revenue mix. It is bottom-up in the sense that it spreads from taxpayers and public service users - variously organized in associations, interest groups, lobbies - onto some elected officials' legislative action. Second, such popularly demanded limits on local governments (where local can refer to municipalities, counties, regions or special purpose districts, depending on the specific institutional arrangements) are not enacted, enforced and tailored to the level of government on which they eventually apply - as in self-imposed limits discussed in section 2.3 below - but are delegated to an higher level of government (typically the states in federal countries) than the local units they bind. Finally, such limits are uniformly applied by that upper tier authority across its entire jurisdiction. This way, it is a transfer from below of the power to limit.

As such, the above definition seems to encompass most of the experiences of state limitation of local government fiscal policy that have emerged in the US states during the 20th century, namely: a) fiscal limitations that are the explicit outcomes of voter-initiated ballots, as 1978 Proposition 13 in California; b) fiscal limitations passed or put out to referenda by legislators in states with the initiative process in order to anticipate or prevent voter-initiated actions (often as a result of initiative events sub a) above having occurred elsewhere in the country); c) fiscal limitations that legislators, even in the absence of formal popular initiative processes and direct access to the ballot in the state, have passed in order to avoid retribution at elections (again likely under the influence of manifestations of a) and b) in other, likely related or nearby, states). 
Some of the existing restrictive arrangements in the US system of local government (particularly property tax limits) date back as early as the 1930s, while they became widespread after California's Proposition 13. As many as 43 US states implemented some kind of property tax limitation within two years of the passage of Proposition 13 (Mullins and Wallin, 2004). Shedbagian (1998) documents that, prior to 1970, only four states (Alrizona, Colorado, Oregon, and Utah) imposed potentially binding limits on local governments' taxing and spending powers. More recently, a large number of US state TELs adoption took place during the 1980s and 1990s: from 1970 to 1992, 26 additional states imposed TELs, and currently 46 US states have some form of local TELs. The vast US literature in this area lists up to seven distinct forms that limits can take: 1) general revenue increases; 2) general expenditure increases; 3) assessment increase limits; 4) property tax levy limit; 5) overall property tax rate limitation; 6) specific property (or other) rate limit; 7) full disclosure, in terms of specific requirements on public discussion or legislative voting procedure prior to the enactment of tax rate (levy) increases. An important distinction as far as the effectiveness of limits is concerned is on whether limits are 'nonbinding' or 'potentially binding.' The former case refers to limits that can be circumvented through alterations in the tax structure parameters that are not explicitly involved in the limitation. A typical example is an attempt to limit property tax levies through caps on statutory tax rates: in fact, the rate limit is substantively nonbinding if it is not coupled with a limit on property tax base assessment increases. General revenue or general expenditure limits are instead potentially binding due to the fixed and universal nature of the constraint, though the extent to which they actually limit spending or revenue growth for governments at the bound-generated corner solution - or the counterfactual 
budget growth if the limit had not been imposed - is of course unobserved. On the other hand, even governments that are observed to set expenditures or revenues strictly below the upper limits might in fact be constrained by them - say if the limit forced the government to renounce to implementation of a bulky new expenditure program.

Whatever their specific form, though, all bottom-up TELs share the feature of having one upper authority - most commonly the state legislature in the US - being transferred from local taxpayers the power to set uniform limits on local governments within its jurisdiction. Possible explanations for this centripetal movement of fiscal regulatory power are discussed in section 3 below.

\subsection{Top-down TELs}

Unlike the US, typical arrangements among European countries have national governments unilaterally setting limits on the fiscal policies - taxes, expenditures or budget deficits - of regional and local governments. The lack of bottom-up processes can be largely explained by the fact that citizen-initiated proposals in fiscal matters are constitutionally ruled out in most European countries.

Interestingly, the historical tendency of central governments across Europe to have preeminence and exercise a tight control on local governments - a sort of Europe-wide Dillon's rule that might seem in contradiction with the European Charter of Local SelfGovernment approved by the member states of the Council of Europe (1985) - has become even more pronounced in recent years. First, adherence to the Maastricht Treaty and the Growth and Stability Pact implied that member countries had to impose an increasing degree of fiscal discipline on all domestic levels of government during the 1990s in order to 
match the EU deficit and debt targets, often formally establishing the budgeting rules and criteria that lower levels of governments had to abide to. Second, the financial crisis of 2007-2008 constituted a tremendous centripetal force in Europe, both in terms of the weakening of EU member state sovereignty over fiscal matters, and of the dwindling of the fiscal autonomy that regional and local governments had progressively achieved. Surprisingly enough, and in spite of those two waves of centralization of fiscal rules, TELs on local governments in EU countries have attracted very little attention, particularly if one considers that local government fiscal autonomy is severely restricted, and increasingly so, across virtually all main European countries.

Interestingly, and unlike what may seem the very spirit of the US tax revolt movement, it is not uncommon to see national governments in Europe set minimum along with maximum tax rates that local governments can set, or even establish tax rate or specific public spending floors only, understandably to prevent the excesses of potentially harmful competition among localities in a 'race to the bottom.'

An example in this latter respect is Germany, a federal country with a rather involved and fragmented local government structure. The by far most important source of revenue for the over 12,000 German municipalities - the local business tax, or trade tax (Gewerbesteuer) is subject to a lower bound only, and an homogeneous one through the whole national territory, irrespective of the state municipalities are located into. Municipalities are allowed to apply a so-called 'multiplier' on a federally set basic business tax rate. The basic federal rate was brought down from 5\% to $3.5 \%$ of the tax base in the 2008 reform of business taxation that also cut the corporate income tax rate from $25 \%$ to $15 \%$. Municipalities can then apply a multiplier that cannot be lower than $200 \%$, while having no upper limitation. 
The municipal multiplier takes an average value of around $400 \%$, amounting to an overall joint municipal-federal tax rate of $14 \%$ on business income (a sort of value added tax base, measured at the plant level), with larger urban areas typically setting higher multipliers (exceeding 500\% in some instances) than smaller rural localities (Fossen and Bach, 2008). Most other European experiences of local tax limitations have either upper limits only ('caps'), or both lower and upper limits. As an instance of the former, the UK system of local government represents an interesting case of study in many respects. First, a large share of total public expenditures is wielded by UK local governments (about one quarter in the early 2010s, including counties, districts and one-purpose authorities), and this has been accompanied by a secular experience in the application of the property tax as the single local tax, from the 'rates' (a proportional tax on business property and domestic hereditaments) to the Council tax. The Council tax, introduced in the early 1990s to replace the short-lived Community Charge (or Poll Tax), constitutes the major source of financing of local governments. While British local authorities enjoy in principle the power to set the Council tax at the level they wish, the only formal constraint being a quasi-proportional schedule obtained via a system of property value bands, the central government retains the power to discretionarily cap local property taxes according to rules that have been changing over time depending on the party in power at the national level (usually Conservative governments putting tougher constraints than Labour ones). Moreover, on the expenditure side, national government agencies set standards and rules on local authorities' outlays on public services, including recurrent mandating of standard service provision and a sophisticated system of evaluation of local government performance in the provision of key public services as health, education and social care. 
In France, a traditionally highly centralized country whose Napoleonic model of administration was exported to several continental countries during the early 19th century, all major local taxes have been subjected to pretty involved limitation schemes. Such centralized control survived the decentralization reform of the 1980s that gave local governments pretty substantial own sources of tax revenues (chiefly the taxes on land, buildings and business assets). However, the fiscal counter-reformation of the latest Sarkozy years somewhat diluted the fiscal decentralization revolution of the Mitterrand era: most notably, the local business tax (taxe professionelle), previously limited to 3.5\% of business value added, was abolished altogether starting January 1, 2010, in an effort to unleash entrepreneurial activity and promote investment, growth and employment (Ministère de l'Economie, de l'Industrie et de l'Emploi, République Francaise: Loi des Finances, 2010), yet depriving the around 36,000 French municipalities and their intermunicipal cooperation and upper-tier departmental structures of one of the most important sources of own tax revenue. The remaining municipal taxes on land and property (Taxe d'Habitation and Taxe Foncière) keep on being subjected to strict central limits on the tax rates.

In Spain, a quasi-federal country, the regional governments (Comunidades autónomas) gained a large share of competencies and financial resources since their creation in 1981, and, following the 1992 reform (Segundos Pactos Autonómicos), accounted in the late 2000s for over a third of public spending and enjoyed substantial tax autonomy. However, the doubling of their debts during the financial crisis of 2007-2009, with large autonomous communities like Catalonia systematically overshooting their deficit targets, induced central government to impose quarterly budget reporting in 2011 , and to assume the right to 
directly intervene in communities' fiscal policies in case of non-compliance with centrally set fiscal discipline rules -- an altogether centralization of the regional tax autonomy (Gobierno de Espana, Ministerio de Hacienda y Administraciones Publicas, Ley Organica de Estabilidad Presupuestaria, 2012). As far as local government is concerned, Spanish municipal authorities (Ayuntamientos) mainly rely on property taxes, vehicle registration taxes and a tax on the increase in value of urban land, whose parameters they can set within the limits set by central government. In particular, the local property tax (IBI, Impuesto sobre Bienes Inmuebles), the most important source of revenue for municipal governments, is subject to lower and upper rate limits of $0.4 \%$ and $1.3 \%$ of the cadastral value of the property $(0.3 \%$ and $0.9 \%$ as far as rural buildings are concerned).

In Italy, while the fiscal decentralization reforms of the 1990s granted significant sources of own revenues to regions and local governments (municipalities and provinces), the state kept on imposing limits on the rates that those authorities could set. In particular, the regions are subject to statutory tax rate limitations for their own revenues: the regional business tax rate can be increased or decreased by one percentage point relative to the nationally set standard rate $(4.25 \%$ on business income measured as plant level value added; the national baseline rate was reduced to $3.90 \%$ in 2008 , leaving regions the faculty to change it by 0.92 percentage points). As far as the regional personal income surcharge is concerned - a proportional surtax on the national progressive personal income tax, and the second most important regional revenue source - regions can set a rate between $0.9 \%$ and $1.4 \%$ of taxable income. The state retains the power to mandate increases in regional taxes to the maximum rates for regions exhibiting budget deficits (Revelli, 2012).

As for local governments, there is a two-tier system: provinces and municipalities. All 
provincial revenue sources are subject to lower an upper rate limitations as discussed in detail in Revelli (2010). The recently reformed municipal property tax (IMU, Imposta Municipale) leaves municipalities the possibility of setting rates within minimum and maximum levels being set nationally. The rate limits amount to a minimum of $0.46 \%$ (reduced to $0.2 \%$ for owner-occupied dwellings) and a maximum of $1.06 \%$ ( $0.6 \%$ for owner-occupied dwellings) of the cadastral value of the property. Similarly to regions, municipalities can also apply a surtax on the national personal income tax: the municipal personal income surcharge rate cannot exceed $0.5 \%$ (raised to $0.8 \%$ in 2007) of the personal income tax base. As for public expenditures, the domestic stability pact (DSP) has over the years put very strict limits on the path of current and capital outlays, as well as allowed municipal budget deficits, depending on the annual financial law. Whether property or business taxes are concerned, the European experience in terms of national limitation of local governments reveals that those limits are present in virtually all countries. In particular, Fossen and Bach (2008) report that both unitary and federal countries - from Portugal to Switzerland - have in place severe limitations on the ability of local governments to tax business, and those limitations are found to most frequently involve property and, where existent, local income taxes too. Therefore, it definitely seems that, in spite of the lack of 'institutional' information that frequently plagues research on local government finance, any attempt to model the behavior of decentralized units in European countries ought to consider that the observed taxation and public spending outcomes are likely to be the result of a constrained optimization process that might actually represent a corner solution at a state-imposed limit. 


\subsection{Self-imposed TELs}

A recently explored issue is the possibility that a limit be imposed by a local government on its own ability to tax and spend, even in the absence of mandates to do so by upper tiers of government. Brooks et al. (2012) are the first to systematically tackle that issue from a theoretical and empirical point of view. They define self-imposed local TELs as laws appearing in the code or charter of a municipality - the equivalent of a (fiscal) constitution in the Brennan and Buchanan (1980) sense - that explicitly: a) establish ceilings for total municipal revenues or outlays; b) cap the overall rate or total revenue generated from a given tax or fee; c) require a referendum to raise an existing tax or fee.

To examine whether this sort of self-imposed local TELs exist at all in US municipalities, Brooks et al. (2012) conducted a survey of 347 municipalities (including all 247 cities with populations of 100,000 or more and a random sample of 100 cities with populations between 25,000 and 100,000 , accounting for over a quarter of the total US population) finding that over 1 in 8 municipalities had an own limit according to the above definition. Their survey showed that those self-imposed limits were generally more restrictive than state-imposed TELs where states imposed fiscal limitations at all, and that they frequently referred to own revenue sources that were not involved by state-imposed TELs. Moreover, many of the self-imposed local TELs had been enacted prior to the tax-revolt following the approval of Proposition 13 in California: half of them were adopted before 1980, with some having been in existence for several decades. Over two-thirds of the local TELs emerging from the survey are written into municipal charters, the rest appearing in municipal codes, and were introduced via city council action or citizen-initiated ballot measure. In most instances, limits cannot be circumvented or repealed by city council action alone, but 
require supermajorities or referenda, and in around half of the cities the self-imposed limits are actually binding. In particular, over half of the self-imposed TELs identified by Brooks et al. (2012) - that are existing in 40 of the sampled cities - involve the property tax in terms of rate, levy and assessment limits, the latter being usually expressed as an allowable annual percentage increase in assessed property value. A number of cities have general revenue or expenditure limits, again typically expressed as an annual allowable percentage increase, as well as sales tax limits capping the rate or restricting the number of taxable items, income tax limits, and user fees limitations.

When investigating the determinants of self-adoption of TELs, Brooks et al. (2012) find that a number of state and municipal institutions can explain the introduction of TELs. First, based on the distinction between 'general law' (the majority of US cities located in Dillon's rule states, only holding the power expressly given to them by the states) and 'home rule' (enjoying a larger degree of autonomy in own institutional design, including fiscal matters), they find that the latter are significantly more likely to set themselves tax limits. Similarly, self-limitations are more likely to appear in cities where voters have access to citizen-initiated legislation through referendum, while the city form of government does not appear to play a role. Finally and interestingly, the structure of the metropolitan area in terms of number of municipalities appears an important factor explaining the decision to adopt a limit: the larger the number of local governmental units, the stronger the market-like competition constraints on local officials arising from households' and businesses' migration threats, and the less urgent the need to explicitly tie tax-setting authorities' hands. 


\section{The rationale for TELs}

The early theoretical investigations of the emergence of TELs focused on the imperfections of the political representation process and on the inability of taxpayers to effectively monitor and control the growth of the public sector due to insurmountable information asymmetry and agency problems. If the political outcome does not reflect the demand of the median voter due to supply-side malfunctioning (budget-maximizing bureaucrats, monopoly power, agenda setting, logrolling, interest group prevalence), direct participation and involvement of the citizenry in the decision-making progress by way of initiatives and referenda aimed at limiting governments might be the appropriate response. Backed by the well-known Brennan and Buchanan (1980) fiscal constitution arguments, formal limitations on representatives' power to tax would be the only way to effectively constrain excessive taxes and wasteful expenditures by Leviathan governments. In addition, TELs might be an optimal response in the presence of changes in the underlying environment due to demandside considerations: because the political process is slow and sluggish, voters may find it beneficial to support a TEL to ensure that change occurs when is needed, particularly in the presence of an increase in the effective tax price of local public services that might be determined by state and federal retrenchment in (matching) grant policy and local tax deductibility provisions on federal income tax returns - phenomena that occurred in the US over the 1970s and 1980s (Alm and Skidmore, 1999). Moreover, periods of high income growth, demographic change and alterations in the distribution of income at the local level would make the passage of TELs more likely. However, those early explanations could not explain a typical feature that TELs have taken 
in federal countries as the US, mainly the fact that voters would systematically choose to delegate to state governments - a further away and harder to control tier of government the power to restrain their own autonomy in managing local public service provision and financing. It seems hard to explain why local tax and spending constraining initiatives would be adopted and applied statewide, irrespective of the possibly highly heterogeneous preferences of taxpayers in individual localities. If the true reason for voter-initiated TELs was the inconsistency of the size and scope of local government with their respective constituencies' wills and preferences, a much better and more effective means to influence or restrain local government would seem to propose local initiatives and limit property or other taxes in a local vote, where the community median voter would be more likely to prevail. Moreover, the local level of government seems the level that is most easily influenced and controlled by the citizenry, and is conventionally believed to be the most responsive to citizens' needs, also due to the threat of household mobility and business relocation.

In fact, Fischel (1989) put forward the argument that the California Supreme Court's decision Serrano vs. Priest caused the tax revolt culminated in Proposition 13 by breaking the prevailing Tiebout-Hamilton equilibrium and divorcing local property wealth from school expenditures: by shifting the education finance burden and equalization to the state, wealthy communities would lose their fiscal advantages and would no longer view the property tax as a fee for public school services (but rather as a deadweight loss to them), and vote for Proposition 13 after the court decision. A weakness of the Fischel (1989) theory, though, is its inability to explain a wide range of tax limitation initiatives in different states. 
More recent contributions have in fact argued that the very existence of fiscal limitations on decentralized governments in multi-tiered structures is a phenomenon that is hard to conceive in terms of the traditional view of decentralized democratic processes as accountability-enhancing mechanisms, and even labeled local TELs as a sort of anomaly (Calabrese and Epple, 2010) or theoretical puzzle (Vigdor, 2004). Nechyba (1997) was among the first to formally tackle the general issue of the genesis of tax limits in multitiered government structures, and tried to explain the observed tax structure (income tax at the state level, property tax at the local level) as a response to a sort of coordination failure. He argued that state command on local fiscal choices (in terms of income tax-funded grants and state-imposed caps on local property tax rates) would arise in equilibrium as an optimal outside enforcement when a collusive agreement to simultaneously introduce local income taxes is not self-enforcing. On the other hand, in a later contribution Vigdor (2004) put forward the argument that statewide local tax limitations could be seen as a way for voters in a jurisdiction to influence tax and expenditure decisions in other jurisdictions. Voters might have preferences for tax policy in other jurisdictions either because they own renteroccupied housing and nonresidential land and structures there (absentee landowners), or because they work in other jurisdictions (nonresident employees) and expect to earn higher wages with lower taxes on structures and capital that raise the marginal product of labor. In addition, support for tax limits might come from 'marginal residents,' or individuals who would relocate to another jurisdiction in the presence of a discrete change in the tax and expenditure mix there. Interestingly, based on data from Massachusetts, Vigdor (2004) found that support for Proposition 2 and 1/2 was higher among voters who lived near, rather than in, high-tax localities, thus corroborating his marginal resident hypothesis. 
Finally, Calabrese and Epple (2010) recently provided a comprehensive political economy model of the emergence of tax limits in the presence of multiple local policy instruments: a proportional income tax that might or not be allowed by state legislation, an ad valorem property tax, spending on a local public good, and a lump sum individual transfer serving the role of redistribution instrument. In particular, and similarly to Vigdor (2004), Calabrese and Epple (2010) find that a set of voters support tax limitations because of their desire to move out of their jurisdiction once the limit is adopted statewide. However, they also show that a second group of voters supports tax limits because they alleviate the distortionary effects of high taxes in central-city. Overall, they conclude that while a large proportion of the population would gain from the imposition of tax limits and therefore vote for them, the welfare of the lowest-income households is reduced as a consequence of the fall in local expenditures on redistribution - an adverse welfare effect that might be offset, though, by a modest increase in redistribution spending at the state level.

Clearly, given the diversity of existing fiscal limitation arrangements across the globe, and the relative thinness of the theoretical research on the foundations and explanations of those limits, it seems that theoretical research in this area could foster our understanding of a phenomenon that stays at the core of actual fiscal federalism structures.

\section{The consequences of tax limits}

Unlike the theoretical literature on the causes of tax and expenditure limitations, the empirical literature on the effects of TELs on various aspects of local public finance and service delivery and quality is enormous, and has recently been reviewed elsewhere (e.g., 
Anderson, 2006; Yuan et al., 2007; Sun, 2013). Consequently, I will only briefly report the main results of the empirical research of the recent decades in section 4.1 below, and devote sections 4.2 and 4.3 to a deeper discussion of recent, original investigations of the consequences of tax limits on two specific and crucial aspects of the behavior of local officials: the sensitivity of local public spending to grants and the degree of fiscal competition among local authorities.

\subsection{Do limits work? Intended and unintended consequences of TELs}

The evidence with respect to whether TELs are an effective instrument to constrain elected officials or whether they become dead letters relies almost entirely on US state and local government data, and is sort of mixed. The early empirical analysis based on US state panel data 1972-1992 by Shadbegian (1998) concluded that TELs had been successful in reducing both the size and growth of local government over those two decades, and that they reduced the reliance on property taxes. In particular, Shadbegian (1998) relied on the distinction between potentially binding limits - i.e., explicit and fixed ceilings on property tax levy, expenditure, and revenue increases - and nonbinding ones - i.e., plain tax rate limits that can be circumvented by tax base (usually property) assessment increases - and focused on the former by building a dummy variable equal to one for a given state in a given year if any of those potentially binding limits was in place. While this approach tends to overlook the specific features of state TELs rules, Shadbegian (1998) did allow for the possibility of TELs adoption endogeneity.

Subsequent analyses have performed finer analyses of the differential impact of TELs based on their specific characteristics, and looked at their effects on local revenue structure, 
spending composition, public service outcomes, interpersonal distribution, and tax base growth. In their review, Yuan et al. (2007) confirm that property tax rate limits that are coupled with assessment limits (potentially binding limits) resulted in the greatest reduction in the growth of per capita property tax revenue, but also show that local governments have reacted to such constraints by relying more heavily on other own sources of revenue such as charges and fees, as also found by Shadbegian (1999) and later by Kousser et al. (2008), who test for the effectiveness of state TELs across US states using a difference-indifferences approach and allowing for heterogeneous effects depending on the legal provision of the limits. They find that TELs are largely ineffective in limiting state spending growth since officials can circumvent those limits by raising money through fees or push fiscal burdens down to lower levels.

As far as their impact on public spending composition and service provision are concerned, Poterba and Rueben (1995) investigated the effects of TELs on wages and employment in the public sector, and did find a negative correlation between limits and wage and employment growth, though they warned from attributing a causal interpretation to the effect given that voter taste for government growth might affect both local public sector labor market outcomes and the enactment of property tax limits.

Most of the subsequent research focused on education outcomes in US school districts, with mixed outcomes in terms of the degree to which student performance in districts subject to tax limitations falls relative to student performance in districts not subject to tax limitations (Figlio, 1997; Downes et al., 1998; Shadbegian, 2003). Much of that research is reviewed in Yuan et al. (2007). As for the financial market consequences of tax limits, Poterba and Rueben (1999) find that state fiscal institutions affect the required return that 
lenders demand when states enter the market for tax-exempt bonds. They estimate that a state with a binding tax limitation statute will face, on average, a borrowing rate between 15 and 20 basis points higher than a state without a tax limitation law.

Finally, some research has focused on the effects of property tax limits on property values in US localities. Bradbury et al. (2001) examine the impact of Proposition 2 and 1/2 in Massachusetts - a cap of $2.5 \%$ on the property tax rate and a limit of $2.5 \%$ on nominal annual growth in municipal property tax revenues that were enacted in 1980 . They rely on the hypothesis of capitalization of spending (particularly local spending on education) in house prices, and on the argument that such tax limitation might introduce a possible source of discrepancy between the actual spending outcomes of communities and what the median voter, marginal homebuyer, or local public officials might select if unconstrained. Bradbury et al. (2001) exploit the fact that Proposition 2 and 1/2 did not bind all communities in the same way, but that some were forced to cut their property taxes over the 1980s, and some were able to override the constraints through referenda, while other were not. Their empirical findings suggest that Proposition 2 and 1/2 significantly reduced school spending, and that constrained communities that were able to increase school spending despite the limitation realized gains in property values, consistent with the view that potential home purchasers considered the attraction of increases in school spending to outweigh the costs of increased taxes to pay for them. Hilber and Mayer (2009) extend Bradbury et al. (2001) analysis by introducing a proxy for the extent of capitalization (the supply of land available for new development) and show that the presence of little undeveloped land leads to larger capitalization into house prices in response to limit-driven spending changes. Moreover they show the persistence of the correlation between housing prices and school spending 
using a larger sample of school districts from 46 US states. Most recently, Hoyt et al. (2011) examine the impact of tax and expenditure limits on housing prices and growth using US state panel data. Their findings indicate that property tax limits as well as general revenue limits push housing prices up. On the other hand, limits on educational spending reduce housing prices, suggesting that it is the relative impact of limits on property levies and expenditures on valuable public services that ultimately determines the impact on housing prices. As for the housing stock, property, revenue and expenditure limits are found to have ambiguous effects.

\subsection{Tax limits and the sensitivity of public expenditures to grants}

While a vast literature (recently reviewed by Inman, 2009) has investigated and sought to explain in various ways the anomalously high response of local spending to grants relative to the response to private income - the so-called flypaper effect by which money from central government sticks where it hits - only some recent papers have explored the potential impact of TELs on the sensitivity of local public spending to exogenous variations in grants. Lutz (2010) conjectures that previous evidence of a flypaper effect might have arisen from state constraints preventing local governments from selecting their preferred bundle of public goods, and provides evidence of equivalence between grants and income from a school finance reform in New Hampshire, one of only five states with no stateimposed limitations on the taxing or spending power of local governments (Lutz, 2010: p. 317).

Brooks and Phillips (2010) offer the first formal statement and explicit empirical test of the hypothesis that restrictive fiscal institutions might be responsible for the flypaper effect. 
They use data on the US Community Development Block Grant (CDBG) program and argue that state TELs may systematically force city governments to underprovide local public goods and increase the stimulative effect of federal grants on city spending. However, since they do not observe either the municipal tax bundle or whether a revenue raising constraint is actually binding in any given city, they have to rely on a state-level index of fiscal constraints and ignore both the municipal choice as to own revenue source diversification and the issue of endogenous selection of a city government into the fiscally constrained status. Interestingly, Brooks and Phillips (2010) find a generally high sensitivity of spending to grants in a period of dramatic retrenchment, while they find only limited evidence of an effect of statutory state-level tax limitations on municipal governments' response to the collapse in CDBG grants. Baicker (2001) analyzes US states' responses to federally mandated increases in public medical spending (mandated expansions in Medicaid coverage). She develops a theoretical model showing that states subject to binding tax limits (legal ceilings) would have to reduce spending on other programs by more when faced with a mandatory spending increase than they would if they were able to raise taxes. While her empirical analysis reveals that all states - with or without limits - offset the mandated Medicaid increase by reducing other public welfare spending, she recognizes that this might be due to the fact that she does not observe whether tax limits are actually binding.

Finally, Revelli (2010) models the local tax mix determination process in the presence of statewide tax limitations and shows how the so-called flypaper effect arises in the endogenously generated constrained tax mix. In particular, local expenditures are shown to be predicted to display a one-for-one response to grants in the presence of binding 
limitations on all local tax revenue sources. Revelli (2010) shows theoretically that a binding cap on just one of the available own revenue sources is enough to generate some form of flypaper effect, in the sense of an excess sensitivity of local public spending to grants, and the above result holds when either upper or lower tax limitations are binding: in fact, local authorities will display an excess sensitivity of public expenditures to grants irrespective of whether they are against lower or upper bounds. Finally, the reaction of local public spending to own tax base shocks will be a function of the (lower or upper) binding tax rate limits. By means of an empirical application to panel data on Italian local governments' budgets, where local authorities are subject to strict and frequently binding upper and lower tax rate limitations, Revelli (2010) shows that authorities that are not fully constrained turn out to be able to smooth out their expenditure profile by offsetting state grant policy through own tax changes, and that the impact of own tax bases on local expenditures depends on whether lower or upper limits are binding in the observed tax mix. In addition, the empirical analysis that allows for endogenous selection into the taxconstrained regime and grant endogeneity offers evidence of excess sensitivity of local public spending to grants, a one-for-one response, in tax-constrained localities, irrespective of whether upper or lower limits bind.

An important corollary of Revelli (2010)'s analysis concerns the very interpretation of the public spending behavior that is conventionally known as the flypaper effect. Since excess sensitivity of local public spending to grants should be predicted to arise, and generally tends to manifest itself, both when grants increase and when they decrease, the flypaper effect label turns out to be a misleading one: an higher sensitivity of local public expenditures to grants than to own revenue sources cannot in general be interpreted as a 
sinister symptom of decentralized government overspending.

\subsection{Tax limits and fiscal competition}

Some recent research has instead investigated the consequences of TELs on the spatial pattern of local fiscal policies. In the past two decades, public economists have increasingly employed spatial econometrics techniques to investigate the phenomenon of horizontal and vertical competition among governments in multi-tiered public sector structures. The use of geographical concepts and methods in empirical work on fiscal federalism - 'geografiscal federalism' (Revelli, 2013) - is justified by the idea that space is an important aspect of multi-tiered fiscal arrangements, as witnessed by the plethora of theoretical work based on the two most prominent spatial concepts in public economics (Oates' decentralization theorem and the Tiebout sorting mechanism) as well as by the common finding that decentralized fiscal policies tend to exhibit positive spatial autocorrelation. Explicit incorporation of TELs in the specification and estimation of fiscal reaction functions seems warranted by the fact that local governments around the world are, as shown above, frequently subject to stringent regulations on their tax and spending decisions, making the ideal paradigm of unleashed intergovernmental competition sort of blurred in practice. In particular, if a local government hits a tax limit, a corner solution model accounting for clustering at the limit seems necessary when empirically investigating fiscal competition phenomena. Overlooking the fact that a number of local authorities might be constrained at the limit is bound to lead to similar problems as the ones that are encountered in non-spatial econometric settings when the dependent variable is limited. In 
particular, estimates of the reaction function slope will tend to be biased. Intuitively, authorities hitting the limits give the false impression of deliberately setting their policies independently of their competitors (in either tax or yardstick competition frameworks), while being in reality constrained by fiscal limitations to do so.

Luna et al. (2007) examine Tennessee counties' option sales taxes between 1975 and 1999, with county tax rates being legally constrained by a state cap of 2.25\% in the 1975-1984 window, and of $2.75 \%$ in the rest of the period. They show that county sales tax rates generally increased over time, with all 95 counties having positive tax rates and about half of them being capped at the maximum rate in 1984, and about $20 \%$ of them reaching the higher bound by 1999 . To examine the role of economic and political factors in the decision to raise sales tax rates and eventually end up against the tax limit, they use a duration model that uses as the key variable the spell of time spent below the tax cap. To allow for neighborhood influences on the probability that a county ends in the corner solution, they use two variables. The first is the average sales tax rate of contiguous counties weighted by population, based on the assumption that larger neighboring counties are more likely to have an impact on the county's tax rate. The second is a dummy variable that takes a value of one for a border county and a value of zero for an interior county, with the expectation that border counties will keep their local tax rates low to limit cross-border shopping arising from combined state and local sales tax differentials. While their survival analysis does not reveal any significant influence from neighboring counties, they acknowledge the complexity of a simultaneous spatial tax competition empirical model and call for further research in this area.

Wu and Merriman (2011) use the introduction of a simplified local telecommunications tax 
in Illinois in 2003 to examine municipalities' tax setting choices in the subsequent years. The new system allowed municipalities to choose a tax rate between 0 and 6 percent of the gross charge for telecommunications purchased at retail. Between 2003 and 2008, the number of municipalities that did not set the tax dropped slightly, while the number of municipalities that were capped at the top rate increased significantly. When analyzing the determinants of the evolution of those tax rates over time, they find evidence of inertia effects in the sense that municipalities that had a zero tax rate at the time of introduction of the tax tended not to set positive tax rates subsequently, and the municipalities that were capped at the maximum rate tended not to revert from there. They do find evidence of neighboring effects, though: once allowing for inertial behavior of corner solution authorities, high or increasing tax rates in adjacent municipalities are estimated to make own tax increases more likely.

Di Porto and Revelli (2013) explicitly model a spatial process in local tax policies in the presence of centrally imposed fiscal limitations. In order to investigate the effect of those limitations on the intensity of intergovernmental competition, they take the conventional empirical model of the fiscal reaction function (the spatial lag specification that does not account for corner solutions at the tax limits) as the benchmark, and implement three empirical approaches to the analysis of spatially dependent limited tax policies: 1) a Bayesian spatial approach for censored dependent variables; 2) a Tobit corner solution model augmented with a spatial lag; 3) a spatial discrete hazard model focusing on the corner solution outcomes. Based on an empirical application to provincial vehicle taxation in Italy, they find that explicitly allowing for corner solutions generated by tax limitations unveils a significantly stronger spatial dependence process than when employing 
conventional approaches. They also show that the performance and usefulness of those modeling approaches depend on their ability to capture the specific features of the institutional framework under consideration, the nature of the state-local government structure and the binding intensity of the tax limitations in force.

\section{Concluding remarks}

Comprehension of the genesis and consequences of tax and expenditure limitations on local governments in multi-tiered structures of government represents an important challenge for scholars in law and economics investigating the extent to which typical democratic rules can limit the discretion or abuse of elected representatives. This chapter has first categorized the observed restrictive fiscal institutions into three main forms (bottom-up, top-down and self-imposed) according to the nature of the process (participatory, hierarchical, or self-disciplining) by which they were originated, and next reviewed the theoretical explanations for the existence of those various forms of limitations on local governments' tax policies, discussing in particular the recent revival of theoretical research in this area after the early and somewhat disputable contributions relying on the imperfections of the political representation process and the inability of taxpayers to effectively monitor and control the growth of the public sector. I have then discussed the empirical evidence on the impact of TELs on a number of aspects of decentralized policymaking, showing that they often fail to achieve their stated objectives in terms of expenditure, taxation or overall local government growth, yet they substantially alter the behavior of lower-level governments in far from predictable ways, particularly as they 
interfere with the process of inter-governmental competition that has long been considered a key ingredient for bringing efficiency into the local public sector, and may significantly alter the sensitivity of local public expenditures to state grants - a long-studied yet little understood empirical phenomenon in inter-governmental fiscal relationships.

In the most recent years, and particularly after the financial crisis and global recession of the late 2000s, the role of top-down limitations on taxation and spending powers has grown considerably in most OECD countries: on one hand, EU member states have increasingly renounced sovereignty over fiscal matters, leaving little leeway to national policy-makers to select their desired fiscal policies in an attempt to smooth out public revenues and expenditures over the business cycle. On the other hand, regional and local governments within most EU states have been losing much of the fiscal autonomy they had achieved during the 1980s and 1990s. Admittedly, the fiscal decentralization reforms that occurred during the 1990s in several western democracies largely failed to attain their stated objectives: the accumulation of sometimes exceedingly large local debts and widespread episodes of local corruption and malpractice are hard to reconcile with the alleged benefits of fiscal federalism in terms of transparency, probity and accountability. In a way, the recent process of renewed fiscal centralization following the sovereign debt crisis burst opens the possibility for a novel scenario of inter-governmental fiscal relationships in a context of hierarchical fiscal limitation rules within tighter than ever local budget constraints, with consequences on the quality of decentralized policy-making that are yet to be discovered. 


\section{References}

Alm, J., Skidmore, M., Why do tax and expenditure limitations pass in state elections? Public Finance Review 27 (1999) 481-510.

Anderson, N., Property tax limitations: An interpretative review, National Tax Journal 59 (2006) 685-694.

Bae, S., Moon, S., Changhoon, J., Economic effects of state-level tax and expenditure limitations, Public Adiministration Review 72 (2012) 649-658.

Baicker, K., Government decision-making and the incidence of federal mandates, Journal of Public Economics 82 (2001) 147-194.

Becker, G., Mulligan, C., Deadweight costs and the size of government, Journal of Law and Economics 46 (2003) 293-340.

Borge, L-E., Tovmo, P., Myopic or constrained by balanced-budget rules? The intertemporal spending behavior of Norwegian local governments, FinanzArchiv: Public Finance Analysis, 65 (2009) 200-219.

Bradbury, K., Mayer, C., Case, K., Property tax limits, local fiscal behavior, and property values: Evidence from Massachusetts under Proposition 2-1/2, Journal of Public Economics 80 (2001) 287-311.

Brooks, L., Phillips, J., An institutional explanation for the stickiness of federal grants, Journal of Law, Economics and Organization, 26 (2010) 243-264.

Brooks, L., Halberstam, Y., Phillips, J., Spending within limits: Evidence from municipal fiscal restraints. Manuscript (2012).

Calabrese, S., Epple, D., On the political economy of tax limits, IEB Institut d'Economia de 
Barcelona Working Paper No. 14/2010.

Council of Europe. 1985. European Charter of Local Self-Government. European Treaty No. 122, Strasbourg.

Di Porto E, Revelli F., Tax-limited reaction functions. Journal of Applied Econometrics forthcoming (2013).

Downes, T., Dye, R., McGuire, T., Do limits matter? Evidence on the effects of tax limitations on student performance, Journal of Urban Economnics 43 (1998) 401-417.

Dye, R., McGuire, T., McMillen, D., 2005. Are property tax limitations more binding over time? National Tax Journal 58: 215-225.

Figlio, D., Did the tax revolt reduce school performance? Journal of Public Economics, 65 (1997) 245-269.

Fischel, W., Did Serrano cause Proposition 13? National Tax Journal 42 (1989) 465-473.

Fossen, F., Bach, S., Reforming the German local business tax - Lessons from an international comparison and a microsimulation analysis, Finanzarchiv 64 (2008) 245272.

Hilber, C., Mayer, C., Why do households without children support local public schools? Linking hose price capitalization to school spending, Journal of Urban Economics, 65 (2009) 74-90.

Hoyt, W., Coomes, P., Biehl, A., Tax limits and the housing markets: Some evidence at the state level, Real Estate Economics 39 (2011) 97-132.

Inman, R., Flypaper effect, in: S. Durlauf and L. Blume (Eds.) The New Palgrave Dictionary of Economics Online, Palgrave Macmillan, 2009.

Joumard, I., Kongsrud, M., Fiscal relations across government levels, OECD Economics 
Department Working Paper 375 (2003).

Kousser, T., McCubbins, M., Moule, E., For whom the TEL tolls: Can state tax and expenditure limits effectively reduce spending? State Politics and Policy Quarterly 8 (2008) 331-361.

Mullins, D., Wallin, B., Tax and expenditure limitations: Introduction and overview, Public Budgeting and Finance 24 (2004) 2-15.

Luna, L., Bruce, D., Hawkins, R., Maxing out: An analysis of local option sales tax rate increases. National Tax Journal 60 (2007) 45-63.

Lutz, B., Taxation with representation: Intergovernmental grants in a plebiscite democracy, Review of Economics and Statistics 92 (2010) 316-332.

Nechyba, T., Local property and state income taxes: The role of interjurisdictional competition and collusion, Journal of Political Economy 105 (1997) 351-384.

Poterba, J., Rueben, K., The effect of property tax limits on wages and employment in the local public sector, American Economic Review, Papers and Proceedings 85 (1995) 384-389.

Poterba, J., Rueben, K., State Fiscal Institutions and the U.S. Municipal Bond Market, in: J. Poterba (ed.) Fiscal Institutions and Fiscal Performance, University of Chicago Press, Chicago (1999), pp. 181-208.

Pudney, S., Modelling Individual Choice. The Econometrics of Corners, Kinks and Holes. Blackwell, Oxford, 1991.

Revelli, F., Tax mix corners and other kinks, IEB Institut d'Economia de Barcelona, Working Paper No. 50/2010.

Revelli, F., Business taxation and economic performance in hierarchical government 
structures, IEB Institut d'Economia de Barcelona, Working Paper no. 12/2012.

Revelli, F., Geografiscal federalism in: G. Brosio, E. Ahmad (Eds.) Handbook of Fiscal Federalism, second edition, Edward Elgar (2013) forthcoming.

Shadbegian, R., Do tax and expenditure limitations affect local government budgets? Evidence from panel data, Public Finance Review 26 (1998) 118-136.

Shadbegian, R., The effect of tax and expenditure limitations on the revenue structure of local government, 1962-87, National Tax Journal 52 (1999) 221-237.

Shadbegian, R., Did the property tax revolt affect local public education? Evidence from panel data, Public Finance Review 31 (2003) 91-121.

Sun, R., Reevaluating the effect of tax and expenditure limitations: An instrumental variable approach, Public Finance Review (2013) forthcoming.

Sutherland, D., Price, R., Joumard, I., Sub-central government fiscal rules, OECD Economic Studies 41 (2005) 141-181.

Vigdor, J., Other people's taxes: Nonresident voters and statewide limitation of local government, Journal of Law and Economics 47 (2004) 453-476.

Yuan, B., Cordes, J., Brunori, D., Bell, M., Tax and expenditure limitations and their effects on local public finances, George Washington Institute of Public Policy (2007).

Wolman, H., McManmon, R., Bell, M., Brunori, D., Comparing local government autonomy across states, Working Paper No. 35/2008, George Washington Institute for Public Policy, Washington.

Wu Y, Merriman D. 2011. Inertia and neighboring effects in local tax policy: Illinois’ experience with a local option tax on telecommunications. Public Budgeting \& Finance 31: $99-116$. 